\title{
Ethylene production by strains of the plant- pathogenic bacterium Pseudomonas syringae depends upon the presence of indigenous plasmids carrying homologous genes for the ethylene-forming enzyme
}

\author{
Kazuhiro Nagahama, ${ }^{1}$ Kuniaki Yoshino, ${ }^{1}$ Masayoshi Matsuoka, ${ }^{1}$ \\ Mamoru Sato, ${ }^{2}$ Sumio Tanase, ${ }^{3}$ Takahira Ogawa' and Hideo Fukuda ${ }^{1}$
}

Author for correspondence: Kazuhiro Nagahama. Tel: +81963263111 ext. 5135. Fax : +81963263000.

\footnotetext{
1 Department of Applied Microbial Technology, Kumamoto Institute of Technology, Ikeda 4-22-1, Kumamoto 860 , Japan

2 National institute of Sericultural and Entomological Science, Tsukuba, Ibaraki 305, Japan

${ }^{3}$ Department of Biochemistry, Kumamoto University School of Medicine, Honjo 2-2-1, Kumamoto 860, Japan
}

\begin{abstract}
The molecular characteristics of the ethylene-forming enzymes of strains of Pseudomonas syringae were tested. The ethylene-producing activities of the nine strains as measured in vivo and in vitro were similar, except for that of $P$. syringae pv. mori M5. A polyclonal antibody and a DNA probe for the ethyleneforming enzyme from $P$. syringae pv. phaseolicola PK2 were prepared to investigate homologies among the proteins and genes for the ethyleneforming enzymes. With the exception of $P$. syringae pv. mori M5, eight strains tested expressed the same antigen as the ethylene-forming enzyme from $P$. syringae pv. phaseolicola PK2 and were homologous to DNA sequences on indigenous plasmids. Molecular masses of antigenic proteins from all ethyleneproducing strains were $\mathbf{4 0} \mathrm{kDa}$. The $\mathbf{N}$-terminal amino acid sequence of the purified ethylene-forming enzyme from $P$. syringae pv. glycinea KN130 was identical to that of the enzyme from $P$. syringae pv. phaseolicola PK2. These results show that the ethylene-forming enzymes encoded by the indigenous plasmid(s) in the pathogenic bacteria examined were similar.
\end{abstract}

Keywords: ethylene production, Pseudomonas syringae pv. glycinea, Pseudomonas syringae pv. phaseolicola

\section{INTRODUCTION}

Ethylene is a plant hormone that is produced by plants (Adams \& Yang, 1979) and a variety of microorganisms, including plant pathogens (Freebairn \& Buddenhagen, 1964; Goto et al., 1985; Sato et al., 1987). There are two biosynthetic pathways for the production of ethylene by micro-organisms (Fukuda \& Ogawa, 1992; Fukuda et al., 1993). In one pathway, ethylene is produced via 2-keto-4-methyl-thiobutyric acid by an NADH: $\mathrm{Fe}(1 \mathrm{II}) \mathrm{EDTA}$ oxidoreductase (Fukuda et al., 1989b; Ogawa et al., 1990). In the other pathway, ethylene is produced via 2-oxoglutarate as, for example, in Penicillium digitatum (Fukuda et al., 1986, 1989a) and in Pseudomonas syringae pv. phaseolicola PK2 (Fukuda et al., 1992b; Nagahama et al., 1991a, b).

Recently, the gene coding for the ethylene-forming enzyme (EFE) of $P$. syringae pv. phaseolicola PK2 was

Abbreviation: EFE, ethylene-forming enzyme. found to be located in an indigenous plasmid, designated pPSP1, and the gene was cloned and expressed in Escherichia coli JM109 (Fukuda et al., 1992a). Nucleotide sequence analysis of the clone revealed an open reading frame that could specify 350 amino acids. The ethylenogenic capability of several pathovars of $P$. syringae was studied (Sato et al., 1987) and it was found that strains of $P$. syringae pv. glycinea isolated from various regions of Japan, which cause halo blight in soybean plants, produced ethylene as efficiently as the Kudzu strains of $P$. syringae pv. phaseolicola. In this study, we describe homologies among the EFEs from several strains of $P$. syringae using polyclonal antibodies and DNA probes derived from the EFE gene of $P$. syringae $\mathrm{pv}$. phaseolicola PK2.

\section{METHODS}

Bacterial strains and growth conditions. Bacterial strains used in this study are listed in Table 1. All strains were maintained on modified nutrient broth agar that contained $\left(1^{-1}\right): 5 \mathrm{~g}$ Polypepton, $3 \mathrm{~g}$ yeast extract, $3 \mathrm{~g}$ meat extract, $2 \mathrm{~g} \mathrm{NaCl}, 5 \mathrm{~g}$ 
Table 1. Strains of $P$. syringae

\begin{tabular}{|cll|}
\hline Strain & Place of isolation & Reference \\
\hline pv. phaseolicola & & \\
PK2 & Shizuoka & Goto et al. (1985) \\
KUZ1 & Ibaragi & Goto et al. $(1985)$ \\
KUZ5 & Ibaragi & Goto et al. $(1985)$ \\
KUZ7 & Yamagata & Goto et al. $(1985)$ \\
pv. glycinea & & \\
KN35 & Iwate & Nishiyama et al. $(1986)$ \\
KN41 & Akita & Nishiyama et al. (1986) \\
KN44 & Ibaragi & Nishiyama et al. $(1986)$ \\
KN130 & Ibaragi & Nishiyama et al. (1986) \\
pv. mori & & Sato (1983) \\
M5 & Miyazaki & Gol
\end{tabular}

*P. syringae pv. phaseolicola PK2 was obtained from Professor M. Goto (Shizuoka University, Shizuoka, Japan). Other strains were obtained from the collection of the National Institute of Sericultural and Entomological Science, Tsukuba, Japan (Nishiyama et al., 1986; Sato, 1983).

glucose and $15 \mathrm{~g}$ agar ( $\mathrm{pH} 7 \cdot 0)$. All chemicals were from Wako Pure Chemical Industries unless otherwise stated. A portion $(2 \mathrm{ml})$ of the seed culture of each strain of $P$. syringae was inoculated into a $500 \mathrm{ml}$ Erlenmeyer flask containing $100 \mathrm{ml}$ of modified nutrient broth medium and was incubated at $30^{\circ} \mathrm{C} \mathrm{fcr}$ $12 \mathrm{~h}$ on a rotary shaker at 180 r.p.m. (70 mm amplitude).

Preparation of cell-free extracts and immunoblot analysis. Bacterial cells in 1 litre of culture broth were pelleted $b_{y}$ centrifugation, suspended in $10 \mathrm{ml} 100 \mathrm{mM}$ potassium phosphate buffer $(\mathrm{pH} 7 \cdot 0)$ and disrupted by sonication (Branson Sonifier, model 350) for $10 \times 30 \mathrm{~s}$ (cooled on ice between each $30 \mathrm{~s}$ period of sonication). Cell debris was removed by centrifugation $\left(15000 \mathrm{~g}, 40 \mathrm{~min}, 4^{\circ} \mathrm{C}\right)$ and the supernatant: were used for the in vitro assay of EFE activity. Proteins ir extracts $(300 \mu \mathrm{g}$ protein per lane) were fractionated by SDS. PAGE on a $10 \%(\mathrm{w} / \mathrm{v})$ gel as described by Laemmli (1970) and were transferred electrophoretically onto nitrocellulose membranes (Bio-Rad) in $25 \mathrm{mM}$ Tris/ $\mathrm{HCl}$ (pH 8.3), $192 \mathrm{mM}$ glycine and $20 \%(\mathrm{v} / \mathrm{v})$ methanol. The membranes were blocked with PBS to which $8 \%(\mathrm{w} / \mathrm{v})$ skim milk was added, and incubated with polyclonal antibodies, raised against the purified EFE (Nagahama et al., 1991b). Unbound antibodies were washed out twice with PBS containing $0.05 \%$ Tween 20 . Antibodies bound to the membranes were detected using peroxidase-conjugated antibodies against rabbit IgG raised in donkeys (Amersham) in $50 \mathrm{mM}$ Tris/ $\mathrm{HCl}$ (pH 7.6), $150 \mathrm{mM}$

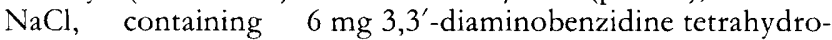
chloride $\mathrm{ml}^{-1}$.

Molecular genetic techniques. Plasmid DNA was isolated by the alkaline lysis method (Birnboim \& Doly, 1979). Southern blotting was performed essentially as described by Meinkoth \& Wahl (1984) using DIG (digoxigenin) DNA Labelling and Luminescence Detection Kits (Boehringer Mannheim). A DIGlabelled DNA probe was made from the $1.5 \mathrm{~kb}$ HindIII-EcoRI fragment that contained the full-length gene for EFE from pPSP1, an indigenous plasmid of $P$. syringae pv. phaseolicola PK2 (Fukuda t al., 1992a). The concentration of DNA probe used in hybridization solution was $4 \mathrm{ng} \mathrm{ml}^{-1}$.

Measurement of ethylene-forming activity in vivo. One millilitre of culture broth (each strain was cultured for $11 \mathrm{~h}$ at $30^{\circ} \mathrm{C}$ ) was transferred to a sterile test tube, which was then sealed with a sterile rubber stopper and incubated on a reciprocal shaker at $30^{\circ} \mathrm{C}$ for $1 \mathrm{~h}$. After incubation, $1 \mathrm{ml}$ air space was withdrawn through the stopper by a syringe and analysed by gas chromatography (gas chromatograph G3800; Yanako), under the following conditions: column size, $3 \mathrm{~mm}$ i.d. $\times 2 \mathrm{~m}$; solid phase, active alumina ; temperature, $100^{\circ} \mathrm{C}$; carrier gas, nitrogen

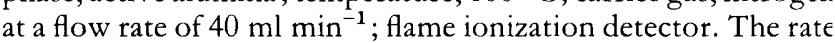
of production of ethylene was calculated as previously described (Nagahama et al., 1991b) and expressed as $\mu \mathrm{l}$ ethylene (mg cell dry $w t)^{-1} h^{-1}$.

Measurement of ethylene-forming activity in vitro. The standard reaction mixture $(1 \mathrm{ml})$ was composed of $2.5 \mathrm{mM} 2$ oxoglutarate, $2 \mathrm{mM}$ L-arginine, $2 \mathrm{mM}$ ferrous sulfate, $10 \mathrm{mM} \mathrm{L}$ histidine, and cell-free extract in $40 \mathrm{mM}$ HEPES buffer, $\mathrm{pH} 8 \cdot 0$ A test tube containing the standard reaction mixture was sealed with a rubber stopper and then incubated with gentle shaking at $25{ }^{\circ} \mathrm{C}$ for $10 \mathrm{~min}$. After incubation, the amount of ethylent formed was determined by gas chromatography, as described above. The activity was expressed as $\mu \mathrm{l}$ ethylene ( $\mathrm{mg}$ protein $)^{-1}$ $\mathrm{h}^{-1}$. Protein concentrations were determined from the absorbance at $280 \mathrm{~nm}$ or by the Lowry method.

Purification of EFE and $\mathrm{N}$-terminal amino acid analysis. Purification of EFE was performed essentially as described by Nagahama et al. (1991b), using chromatography columns of Butyl-Toyopearl 650M, DEAE-Sepharose CL-6B, Bio-Gel H'T and Sephadex G-100. The N-terminal amino acid residues of the purified enzyme of $P$. syringae pv. glycinea KN130 (20 mg equivalent to approximately $480 \mathrm{pmol}$ ) were determined by automated Edman sequencing with an amino acid sequences (model 477A; Applied Biosystems).

\section{RESULTS AND DISCUSSION}

\section{Comparison of ethylene-forming activities in vivo and in vitro among different strains of $P$. syringae}

With the exception of $P$. syringae pv. mori M5, all strains of $P$. syringae tested produced ethylene from 2-oxoglutarate (Table 2). Since activities of EFE in vivo and in vitro were 
Table 2. Rates of ethylene formation by strains of $P$. syringae

\begin{tabular}{|c|c|c|}
\hline \multirow[b]{2}{*}{ Strain } & \multicolumn{2}{|c|}{ Specific activity* } \\
\hline & in vivo $\dagger$ & in vitro $\ddagger$ \\
\hline \multicolumn{3}{|l|}{ pv. phaseolicola } \\
\hline PK2 & $1 \cdot 2$ & $0 \cdot 9$ \\
\hline KUZ1 & $1 \cdot 4$ & $0 \cdot 8$ \\
\hline KUZ5 & $1 \cdot 7$ & $2 \cdot 5$ \\
\hline KUZ7 & $1 \cdot 0$ & $3 \cdot 8$ \\
\hline \multicolumn{3}{|l|}{ pv. glycinea } \\
\hline KN35 & 0.5 & $0 \cdot 3$ \\
\hline KN41 & $0 \cdot 7$ & $0 \cdot 4$ \\
\hline KN44 & $1 \cdot 1$ & $0 \cdot 8$ \\
\hline KN130 & 1.9 & $1 \cdot 2$ \\
\hline \multicolumn{3}{|l|}{ pv. mori } \\
\hline M5 & $0 \cdot 0$ & $0 \cdot 0$ \\
\hline
\end{tabular}

* The values represent the means of three independent experiments with a reproducibility of $\pm 5 \%$ or better.

$\dagger \mu l$ ethylene (mg cell dry wt $)^{-1} h^{-1}$.

$\ddagger \mu l$ ethylene (mg protein) $)^{-1} \mathrm{~h}^{-1}$.

affected by the culture conditions and the duration of cultivation, these results do not correspond to the maximum activities of ethylene production for each strain. Nevertheless, within the range of standard conditions of in vivo and in vitro assays (error $\pm 5 \%$ ) $P$. syringae $\mathrm{pv}$. mori M5 did not produce ethylene at all.

\section{Plasmids carrying homologous EFE genes}

A DN $A$ fragment carrying the entire coding region of EFE from the indigenous plasmid, pPSP1, of $P$. syringae pv. phuseolicola PK2 (Fukuda et al., 1992a) was used to probe the related genes in $P$. syringae strains. Size separation analysis of indigenous plasmids from different bacterial strains gave different electrophoretic patterns
(Fig. 1a). Southern blot analysis showed that eight of the ethylene-producing strains harboured indigenous plasmids carrying sequences homologous to the EFE gene (Fig. 1b). P. syringae pv. glycinea KN130 contained two plasmids, and $P$. syringae pv. glycinea KN35 contained several plasmids carrying the homologous EFE gene sequence (Fig. 1b, lanes 8 and 5). In other strains, only one plasmid hybridized. In contrast, genomic and plasmid DNAs from $P$. syringae pv. mori M5 did not hybridize. These results suggest that in strains of $P$. syringae pv. phaseolicola and $P$. syringae pv. glycinea indigenous plasmids may be involved in ethylene production. So far, plasmids have been detected in a number of plant-pathogenic bacteria but the plasmids differed in their sizes even within the same species (Coplin et al., 1981; Curiale \& Mills, 1983).

\section{Ethylene-forming enzyme in various strains}

Immunoreactive protein bands with the same mobility (about $40 \mathrm{kDa}$ ) as the purified EFE from P. syringae pv. phaseolicola PK2 were detected in the extracts of the different ethylene-producing strains (Fig. 2). Minor staining bands, especially in the extracts from $P$. syringae pv. mori M5, were due to the nonspecific binding of peroxidase-conjugated anti-rabbit IgG antibody. This nonspecific binding was confirmed in the control experiment in which polyclonal antibodies were removed from the assay system (Fig. 2b, lane 10).

The analysis of the $\mathrm{N}$-terminal amino acid sequence (Fig. 3) of EFE from $P$. syringae pv. glycinea KN130 revealed that the first 30 residues were identical to those from $P$. syringae pv. phaseolicola PK2 with the possible exception of an unidentified residue at position 16 .

These data suggested that all eight ethylene-producing strains expressed proteins having the same antigenic properties as the EFE from $P$. syringae pv. phaseolicola $\mathrm{PK} 2$, and that the EFEs from $P$. syringae pv. glycinea KN130 and $P$. syringae pv. phaseolicola PK2 were identical proteins. (a)

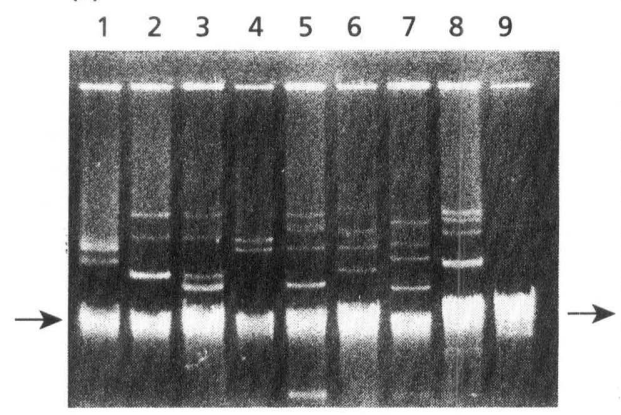

(b)

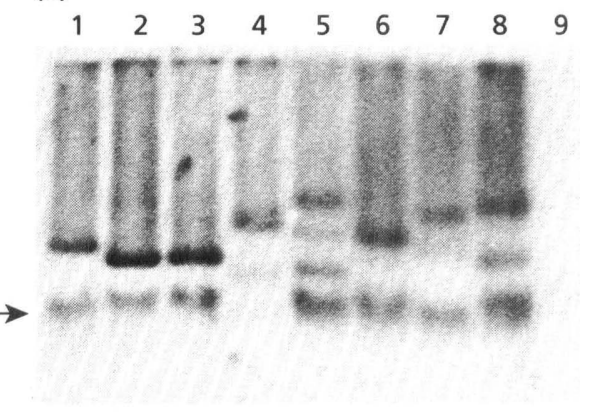

Fig. 1. Electrophoretic and Southern analysis of plasmid DNA from Pseudomonas syringae strains. (a) Ethidium bromidestained gel showing several plasmid patterns. (b) Southern blot analysis with the EFE probe (1.5 kb HindIII-ECoRI fragment of the full-length gene for EFE from plasmid pPSP1). Lanes: $1, P$. syringae pv. phaseolicola PK2; $2, P$. syringae pv. phaseolicola KUZ1; 3 , P. syringae pv. phaseolicola KUZ5; 4, P. syringae pv. phaseolicola KUZ7; 5 , P. syringae pv. glycinea KN35; 6, P. syringae pv. glycinea KN41; 7, P. syringae pv. glycinea KN44; 8, P. syringae pv. glycinea KN130; 9 , $P$. syringae pv. mori M5. The arrow indicates the position of chromosomal DNA. 

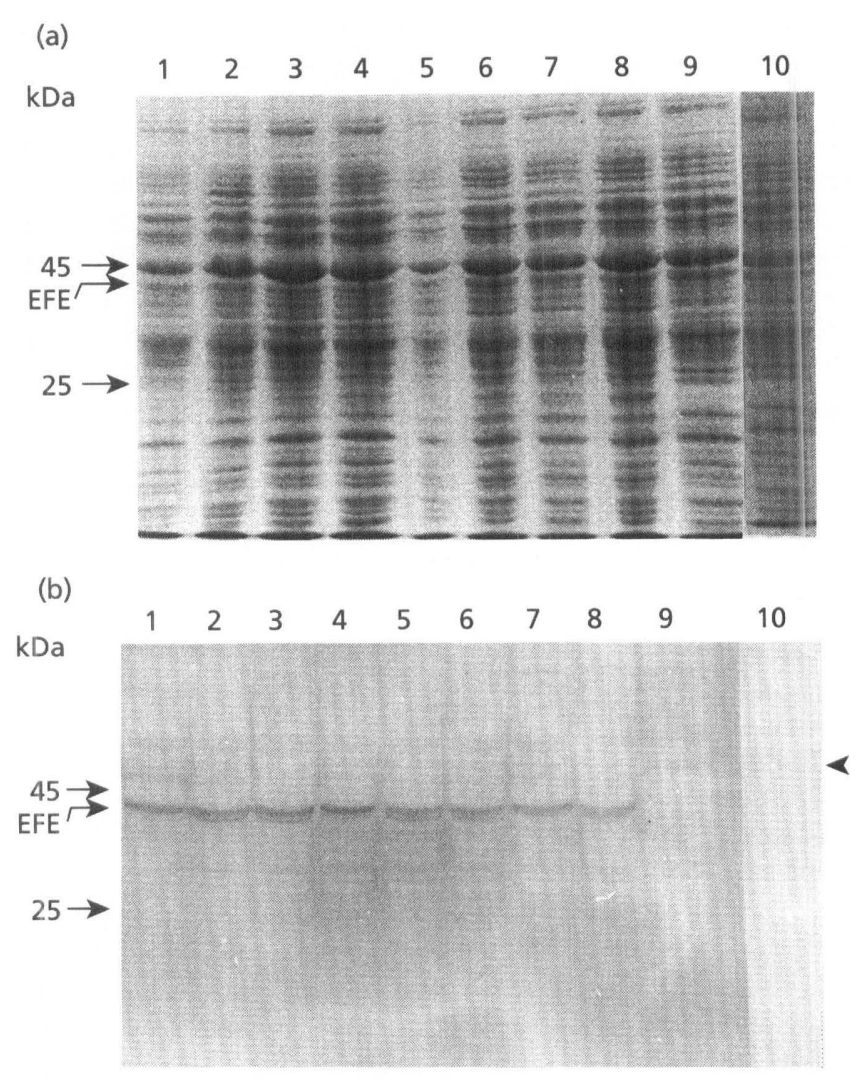

Fig. 2. SDS-PAGE and immunoblot analysis of cell-free extracts from strains of Pseudomonas syringae. (a) SDS-PAGE of the cellfree extract. (b) Western blot with the EFE-specific polyclonal antibody raised against EFE from $P$. syringae pv. phaseolicola PK2. Lanes: $1, P$. syringae pv. phaseolicola PK2; $2, P$. syringae pv. phaseolicola KUZ1; 3, P. syringae pv. phaseolicola KUZ5; 4, $P$. syringae pv. phaseolicola KUZ7; $5, P$. syringae pv. glycinea $\mathrm{KN} 35 ; 6, P$. syringae pv. glycinea KN41; $7, P$. syringae $p v$. glycinea KN44; 8 , P. syringae pv. glycinea KN130; 9, P. syringae pv. mori M5; 10, negative control for $P$. syringae pv. mori M5 without the EFE antibody in the reaction mixture for Western blotting. Arrows indicate the molecular markers and the purified EFE of $P$. syringae pv. phaseolicola PK2. The arrowhead indicates a band for nonspecific binding of peroxidaseconjugated anti-rabbit IgG antibody.

$\begin{array}{lllllllllllllll}1 & 2 & 3 & 4 & 5 & 6 & 7 & 8 & 9 & 10 & 11 & 12 & 13 & 14 & 15\end{array}$ Met-Thr-Asn-Leu-Gln-Thr-Phe-Glu-Leu -Pro-Thr-Glu-Val-Thr-Gly-

$\begin{array}{lllllllllllllll}16 & 17 & 18 & 19 & 20 & 21 & 22 & 23 & 24 & 25 & 26 & 27 & 28 & 29 & 30\end{array}$

$X$ - Ala- Ala-Asp- Ile- Ser- Leu-Gly-Arg-Ala-Leu- Ile-Gin-Ala-Lys-

Fig. 3. N-terminal amino acid sequence of the EFE from $P$. syringae pv. glycinea KN130. X, Unidentified residue.

\section{CONCLUSIONS}

Among the nine strains studied here, P. syringae pv. glycinea strains KN35 and 130 seemed to possess several copies of the EFE gene on different plasmids (Fig. 1b). The EFE protein from P. syringae pv. glycinea KN130 was purified from a cell-free extract and was found to have an $\mathrm{N}$-terminal amino acid sequence the same as that of the previously characterized enzyme from $P$. syringae $\mathrm{pv}$. phaseolicola PK2 (Fig. 3). Moreover, immunoblot analysis showed that the EFE proteins from different strains had the same molecular mass (Fig. 2b). These results are consistent with the hypothesis that the EFE expressed in $P$. syringae pv. glycinea $\mathrm{KN} 130$ is identical to or closely related to that in other EFE-producing strains of $P$. syringae and all genes for EFEs are present on indigenous plasmids.

The purified EFE from Penicillium digitatum IFO 9372 produces ethylene from 2-oxoglutarate (Fukuda et al., 1986, 1989a), but did not react with the polyclonal antibody raised against the EFE from $P$. syringae pv. phaseolicola PK2 (data not shown). The N-terminal amino acid sequence of this fungal EFE was different from that of the bacterial enzyme (Nagahama et al., 1991b). Since at least two strains of Pseudomonas possess EFE proteins with the same $\mathrm{N}$-terminal sequence, important information about ethylene production by 2-oxoglutarate-dependent micro-organisms may be obtained by comparing the bacterial EFEs with fungal EFE such as that from Penicillium digitatum IFO 9372.

\section{ACKNOWLEDGEMENT}

We are grateful to Dr K. Nishiyama, National Institute of AgroEnvironmental Science, for supplying bacterial strains.

\section{REFERENCES}

Adams, D. O. \& Yang, S. F. (1979). Ethylene biosynthesis: identification of 1-aminocyclopropane-1-carboxylic acid as an intermediate in the conversion of methionine to ethylene. Proc Natl Acad Sci USA 76, 170-174.

Birnboim, H. C. \& Doly, J. (1979). A rapid alkaline extraction procedure for screening recombinant plasmid DNA. Nucleic Acids Res 7, 1513-1523.

Coplin, D. L., Rowan, R. G., Chisholm, D. A. \& Whitmoyer, R. E. (1981). Characterization of plasmids in Erwinia stewartii. Appl Environ Microbiol 42, 599-604.

Curiale, M. S. \& Mills, D. (1983). Molecular relatedness among cryptic plasmids in Pseudomonas syringae pv, glycinea. Phytopathology 73, 1440-1444.

Freebairn, H. T. \& Buddenhagen, I.W. (1964). Ethylene production by Pseudomonas solanacearum. Nature 202, 313-314.

Fukuda, H. \& Ogawa, T. (1992). Microbial production. In The Plant Hormone Etbylene, pp. 279-292. Edited by A. K. Matto \& J. C. Suttle. London: CRC Press.

Fukuda, H., Fujii, T. \& Ogawa, T. (1986). Preparation of a cell-free ethylene-forming system from Penicillium digitatum. Agric Biol Chem 50, 977-981.

Fukuda, H., Kitajima, H., Fujii, T., Tazaki, M. \& Ogawa, T. (1989a). Purification and some properties of a novel ethylene-forming enzyme produced by Penicillium digitatum. FEMS Microbiol Lett 59, $1-6$.

Fukuda, H., Takahashi, M., Fuji, T., Tazaki, M. \& Ogawa, T. (1989b). An NADH:Fe(III)EDTA oxidoreductase from Crypto- 
coccus albidus: an enzyme involved in ethylene production in vivo? FEMS Microbiol Lett 60, 107-112.

Fukuda, H., Ogawa, T., Ishihara, K., Fujii, T., Nagahama, K., Omata, T., Inoue, Y., Tanase, S. \& Morino, Y. (1992a). Molecular cloning in Escherichia coli, expression and nucleotide sequence of the gene for the ethylene-forming enzyme of Pseudomonas syringae pv. phaseolicola PK2. Biochem Biophys Res Commun 188, 826-832.

Fukuda, H., Ogawa, T., Tazaki, M., Nagahama, K., Fujii, T., Tanase, S. \& Morino, Y. (1992b). Two reactions are simultaneously catalyzed by a single enzyme: the arginine-dependent simultaneous formation of two products, ethylene and succinate, from 2oxoglutarate by an enzyme from Pseudomonas syringae. Biochem Biophys Res Commun 188, 483-489.

Fukuda, H., Ogawa, T. \& Tanase, S. (1993). Ethylene production by microorganisms. In Advances in Microbial Pbysiology, pp. 275-306. Edited by A. H. Rose. London: Academic Press.

Goto, M., Ishida, Y., Takikawa, Y. \& Hyodo, H. (1985). Ethylene production by the kudze strains of Pseudomonas syringae pv. phaseolicola causing halo blight in Pueraria lobata (Willd) Ohwi. Plant Cell Pbysiol 26, 141-150.

Laemmli, U. K. (1970). Cleavage of structural proteins during the assembly of the head of bacteriophage T4. Nature 227, 680-685.

Meinkoth, J. \& Wahl, G. (1984). Hybridization of nucleic acids immobilized on solid supports. Anal Biochem 138, 267-284.

Nagahama, K., Ogawa, T., Fujii, T., Tazaki, M., Goto, M. \&
Fukuda, H. (1991a). L-Arginine is essential for the formation in vitro of ethylene by an extract of $P$ seudomonas syringae. J Gen Microbiol 137, 1641-1646.

Nagahama, K., Ogawa, T., Fujii, T., Tazaki, M., Tanase, S., Morino, Y. \& Fukuda, H. (1991b). Purification and properties of an ethyleneforming enzyme from Pseudomonas syringae. J Gen Microbiol 137, 2281-2286.

Nishiyama, K., Azegami, K., Osada, S., Nakasone, W., Ezuka, A. \& Watanabe, Y. (1986). Bacterial diseases of soybean and their pathogens in Japan. Bull Natl Inst Agro-Environ Sci 1, 83--94.

Ogawa, T., Takahashi, M., Fujii, T., Tazaki, M. \& Fukuda, H. (1990). The role of NADH:Fe(III)EDTA oxidoreductase in ethylene formation from 2-keto-4-methylthiobutyrate. I Ferment Bioeng 93, 177-181.

Sato, M. (1983). Phage-induction from lysogenic strains of Pseudomonas syringae pv. mori by an extract from mulberry leaves. Ann Pbytopatbol Soc Japan 49, 259-261.

Sato, M., Urushizaki, S., Nishiyama, K., Sakai, F. \& Ota, Y. (1987). Efficient production of ethylene by Pseudomonas syringae pv. glycinea which causes halo blight in soybeans. Agric Biol Chem 51, 1117-1178.

Received 17 January 1994; revised 17 March 1994; accepted 20 April 1994. 